\title{
Tercentenary of the first English book on tropical medicine, by Thomas Trapham of Jamaica
}

\author{
M T ASHCROFT
}

British Medical fournal, 1979, 2, 475-477

Between 11 and 12 o'clock in the morning of 7 June 1692 occurred one of the most famous earthquakes in history, and the town of Port Royal in the island of Jamaica, described by writers of the time as the "Babylon of the Caribbean" and "the wickedest and richest city in the New World," slid into the sea. A contemporary pamphlet ${ }^{1}$ described the disaster and illustrated it with a crude woodcut, showing that "Dr Trapham, a Physician in this Place was Miraculously saved, by hanging by the Hands upon the Rack of a Chimney and one of his children hanging about his Neck, were both saved by a Boat; but his Wife and the rest of his Children and Family were Lost." This drawing (fig 1) is the only pictorial representation known to exist of $\mathrm{Dr}$ Thomas Trapham, author of the first book in English on medicine in the tropics, $A$ Discourse of the State of Health in the Island of famaica. With a provision therefore calculated from the air, the place and the water; the custom and manner of living, etc, published in London in 1679, 13 years before the earthquake and 300 years $\mathrm{ago}^{2}$ (fig 2 ).

\section{Early life}

Trapham was born in England, and some facts of his early life have been recorded in connection with his father, who for a short while was a person of some consequence. ${ }^{3}$ Thomas Trapham, senior, was licensed by the University of Oxford to practise

\footnotetext{
Medical Research Council Laboratories, University of the West Indies, Kingston 7, Jamaica

M T ASHCROFT, DM, DSC, epidemiologist
}

surgery in 1633. He prepared and donated a skeleton to the anatomy school in 1634. At the outbreak of the Civil War in 1642 he joined the Parliamentary forces, eventually becoming a surgeon-general and "body-surgeon" to Oliver Cromwell at the battle of Worcester in 1650 . He is chiefly remembered for sewing back the head to the body of the executed king, Charles I, in 1649, and for embalming the reconstituted corpse. After the Restoration he retired to Abingdon, a centre for his fellow nonconformists, where he quietly practised until his death in 1688, leaving all his wordly possessions to his wife, Elizabeth.

His son, Thomas Trapham, junior, with whom we are concerned, was a demy at Magdalen College, Oxford, from 1654 to 1658 , when he was senior collector of determining bachelors. In 1661 he proceeded MA at Magdalen Hall. In 1663 he attended Leyden University in the Netherlands and obtained his MD at Caen in France in 1664. In December of the same year he was admitted as one of the first honorary fellows of the College of Physicians, London, an order that had been instituted for the dual purpose of drawing into the college all physicians practising in London and of augmenting its finances. In 1667 he married, at Stoke Newington, Mrs Susannah Coxe. Munk, in his Roll of the Royal College of Physicians of London, from which these facts are taken, stated that Trapham was supposed, erroneously, as we now know, to have been swallowed up by an earthquake."

\section{Physician in Jamaica}

It is not known what influenced Trapham to seek his fortune in Jamaica, but he is next heard of in a letter ${ }^{5}$ from Sir Thomas Lynch, Lieutenant-Governor of Jamaica, to Dr Benjamin Worsley, dated 12 August 1673, in which Lynch "heartily thanks him for all and this by the Portland and Dr Trapham," which indicates that Trapham arrived in Jamaica in the Portland in 1673 and not, as has hitherto been believed, in 1675 with the next governor, Lord Vaughan. 




FIG 1-Detail from woodcut in pamphlet describing 1692 earthquake in Port Royal. At bottom left (P) Dr Trapham is shown clinging to his house with a child on his shoulders while the rest of his family is drowning.

(By courtesy of Institute of Jamaica)

Some fragments have come down to us of his life as a physician in Jamaica. He must have been of some importance, judged from the letter mentioned above and from the assumption that he was personal physician to Lord Vaughan; which is supported by the fulsome dedication of the Discourse to that eminent person, who was, as Earl of Carbery, later president of the Royal Society. In 1688, in consultation with Dr Fulke Rose (an active politician and wealthy landowner, whose widow was to marry $\mathrm{Dr}$ Hans Sloane in 1695), he treated a visitor, Mr John Taylor, for a quotidian fever. ${ }^{-}$The doctors, after venesection and the administration of an emetic, "gave it their opinion that he would die of this distemper which continued violently upon him until the end of January with no signs of amendment nor hopes of recovery." Despite these prognostications, Taylor recovered and hastily left the island lest worse befall.

Later in 1688 Trapham, as "one who understood the country diseases having lived there several years," was called into consultation with Dr Hans Sloane for treatment of the Governor, the Duke of Albemarle, who had come to Jamaica, with Sloane as his personal physician in the previous year. Sloane was to become one of the most famous of all British physicians. According to Sloane, T Trapham recommended that the Duke should be removed from Port Royal for a change of air. At a second consultation, in Sloane's words, "He (Trapham).came in the morning before day, his Grace being asleep. I told him his Grace's condition and what I had given him and when his Grace affirmed it, advised him to take a grain of Bird Pepper in a potched egg, affirming parrots do flye to this as to a naturel remedy, and that it was very necessary for everyone to take it in this climate." But Sloane "declined quarreling with him. Thought my case hard enough in that I was blamed by some for want of success when his Grace would not take advice." The Duke died on 6 October 1688. A rumour spread that he had been badly treated, and the Minutes of the Council ${ }^{8}$ recorded, "Dr Trapham and the rest of his Grace's physicians, desiring admittance, were called in, who desired that this Board would appoint someone to view his Grace's corps, which they are now going to Embalme, because there is a Report spread abroad that they have not dealt farly with Him." Two days later it was recorded that "Coll Freeman and Coll Ballard made their Report, that they went to view his Grace's Body, which being opened by the doctors and Chirurgeons present: they saw that his Vitals were very defective except his Heart and it was the opinion of all those present that he could not longer subsist." Trapham and Sloane had been exonerated.

\section{Local politician}

Trapham's first entry into local politics was in early 1677 when he was elected to the House of Assembly (a branch of the Jamaican legislature) to represent the parish of St Mary, but he was not returned in another general election held towards the end of the same year. He did not rejoin the Assembly: until 1695 when he was elected as a member for St Thomas-in-theEast. He was an active politician at this time and in 1696 repeatedly requested assistance for the inhabitants of his parish who had suffered severely in a raid by the French in $1695 .^{\circ}$ $\mathrm{He}$ also moved a resolution that advantage should be taken of the "bath to windward" for medical purposes, and an Act to that effect was passed. ${ }^{10}$

So began the popular Bath of St Thomas-the-Apostle, whose mineral waters have been used with hope right down to the present day. In 1702 Trapham was elected to represent the

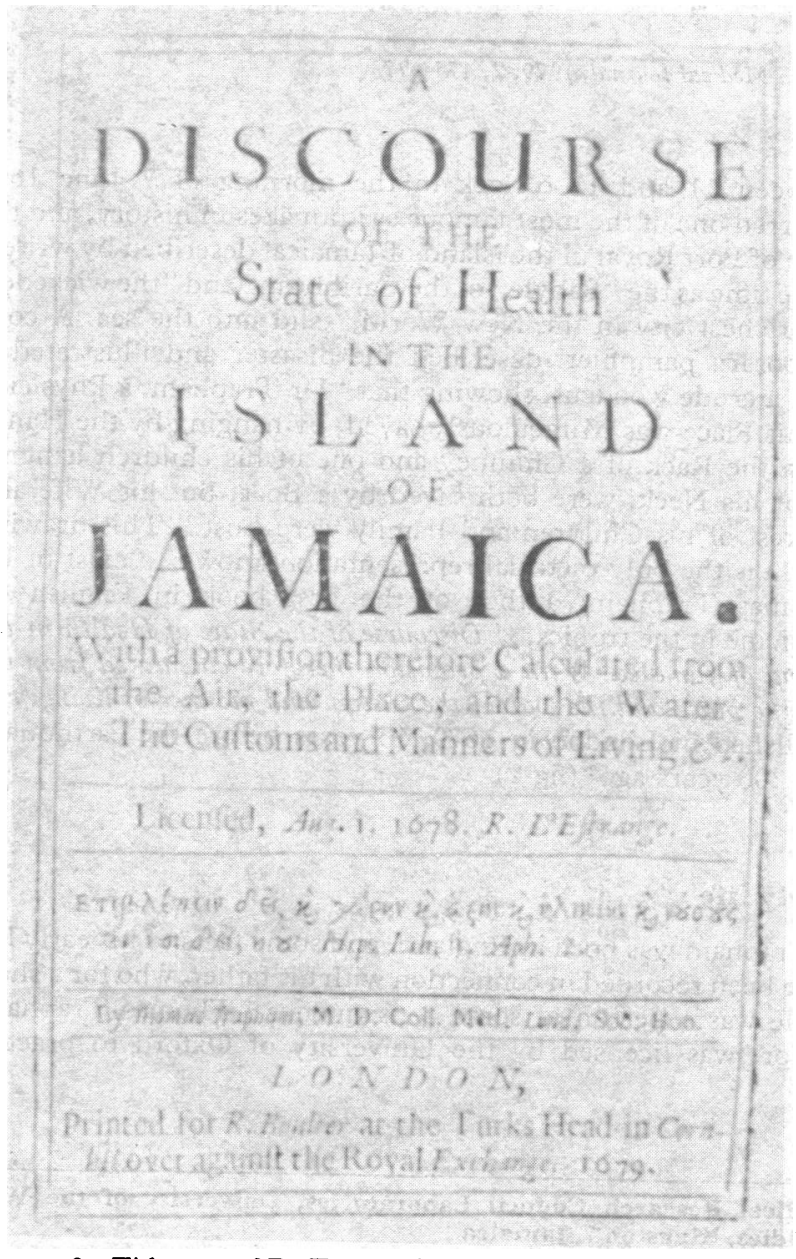

FIG 2-Title page of Dr Trapham's book, printed 300 years ago. (By courtesy of Institute of Jamaica) 
parish of St James but the journals of the House recorded that on 17 April "Doctor Trapham, being indisposed, on request had leave to repair home for the recovery of his health." 11 His name does not occur in the journals again.

\section{His family life}

An account of Trapham's activities as a planter and some information on his family life may be found in a series of deeds and indentures in the Archives and in the Island Record Office of Jamaica. Soon after his arrival, he took out, in 1674, a patent for 1500 acres of land in the parish of St Mary, which was just being opened up for settlement. ${ }^{12}$ In 1677 he went into partnership with Thomas St Nicholas for this sugar estate, which was later known as Hermitage. In 1679 they were both found guilty in the grand court for debts due to the Royal Africa Company, probably for the purchase of slaves. Part of Hermitage and 22 slaves "marked with TST on ye right shoulder" had to be mortgaged to pay the debts. ${ }^{13}$ In 1684 St Nicholas seems to have been replaced as a partner by. George Robinson, who was later bought out by Trapham's son, Thomas Trapham junior, in 1693. ${ }^{14}$ In 1700 the doctor showed solicitude for his daughter, Elizabeth, by signing a deed requesting that she should be maintained by his son until she reached the age of 17 or married; if his son did not maintain her then she would be entitled to repossess her part of Hermitage. ${ }^{15}$ In 1708 this deed of gift was confirmed and Trapham's signature was witnessed, suggesting that he was then on the island. ${ }^{16}$ It had previously been assumed that he left in 1702, after getting permission for health reasons from the House of Assembly. Nothing is known of him after 1708. The absence of a will or a personal inventory in the Jamaican archives suggests that he died elsewhere.

The documents referred to show that two of his children, Thomas and Elizabeth, survived the 1692 earthquake in Port Royal, and no mention has been found of any other children or of a second marriage. One wonders which of the children was saved by hanging on to the doctor's shoulders as he clung to the chimney rack of his ruined house. Probably it was Elizabeth, as Thomas would have been too old as he was concerned in a land transaction a year later. ${ }^{14} \mathrm{He}$ may not have been with the rest of the family in Port Royal at the time of the earthquake.

As to the subsequent lives of these two children, Elizabeth made a will that, according to the Index to Wills in the Island Record Office, was copied in one of the volumes of wills in 1735, but this particular volume is missing and the original will cannot be traced. Presumably, as her name was recorded as Trapham, she had not married. Thomas Trapham, junior, sold part of Hermitage in a series of land transactions to Heathcote Jackson in $1741 .^{1718}$ These dealings may explain why the locality in which the estate was situated is today known as Jackson. A map accompanying one of the transactions ${ }^{18}$ marks adjacent land as belonging to William Hermit, "a natural son of Thomas Trapham," who may have taken his name from that of the estate. This is the last record in Jamaica of Thomas Trapham, junior, and no other children have been traced. Today the names of Hermitage and Trapham cannot be recalled but some people living in the area with the surname Hermit may have "roots" that might be traced back to Dr Trapham as well as to African ancestors.

\section{Trapham's Discourse}

The book $A$ Discourse on the Health of the Island of Famaica is short and the language is often to our minds more colourful and quaint than clear. Trapham first gives an account of the climate, topography, waters, and customs of Jamaica, all of which, according to the revered Hippocrates (one of whose aphorisms grace the title page) influence disease. He clearly liked Jamaica, and he occasionally waxes lyrical on the beauties of the scenery and of certain plants. Chapters then follow on fevers, worms, venereal disease (which he confuses with yaws), and the endemic disease of the West Indies, the dry belly-ache. He likens the severe colic seen in that condition to the sufferings of cattle poisoned by fumes from lead mines in Derbyshire, but he does not directly attribute the dry belly-ache to lead poisoning, evidence of which was obtained many years later.

Like all doctors of his time, his understanding of aetiology is dismayingly erroneous. Most diseases, he believes, are caused by factors such as sudden chilling, exposure to night airs, and intemperance, and are influenced by changes in the lunar cycle. His treatment included the use of emetics, cathartics, venesection, mercurials, and various herbal remedies, which, when not positively injurious, would have been ineffectual. His treatment, however, is less drastic than that of many later Jamaican physicians, and he believed in natural cures. He writes, "For my greater Master tells me, Nature is the cure for all diseases, the physitian is but the observing Minister to suggest her necessaries and remove impediments." Among his general recommendations for health were warm baths and a diet containing large amounts of cocoa. In general, Trapham thinks that the health of Jamaica at that time was relatively good. In his own words, "As for the diseases usually brought here they are far short of the long bedroll which infest our native country." He records that there was little smallpox, no scurvy, no plague, infrequent consumption, and that bladder and kidney stones were rare. Conditions were to deteriorate in the eighteenth century when the "fatal climate" of Jamaica was notorious and greatly feared.

Trapham made no great discoveries and, outside Jamaica, had little influence but he was one of the first of generations of British doctors in the West Indies who struggled ineffectually against the fearful ravages of tropical diseases of which they had gained no experience in Europe. Tropical medicine was hardly recognised as a subject for which special medical training was required until the beginning of the present century. The medical profession in the West Indies was numerous and active in the seventeenth, eighteenth, and nineteenth centuries, and many members played an important part in the community, like Trapham, being authors, planters, and politicians as well as physicians. The fact that the first English book on tropical medicine was written 300 years ago by Thomas Trapham of Jamaica should remind us of these early, but mostly forgotten, British doctors in the tropics.

The research was helped by a grant from the Wellcome Trust.

\section{References}

1 Port Royal, $A$ true and perfect relation of that most sad and terrible earthquake at Port Royal in Famaica, which happened on the 7th of fune, 1692, with the manner of it in a letter written by Captain Crocket. London, printed by R Smith, 1692.

2 Trapham, T, $A$ Discourse of the State of Health in the Island of Famaica, etc. London, Boulter, 1679.

${ }^{3}$ Peachey, G C, Proceedings of the Royal Society of Medicine, 1931, 24, 1141.

4 Munk, W, The Roll of the Royal College of Physicians of London, 7, 345. London, Royal College of Physicians, 1878.

${ }^{5}$ Calendar of State Papers, Colonial Series, American and the West Indies, 1669-1674, art 1130.

6 Taylor, J, Second Part of the Historie of his Life and Travels in Famaica, p 182. Institute of Jamaica, MS, 1688 .

7 Sloane, H, British Library, Sloane MS 3984, ff 282-285. (Quoted by E Ward in Christopher Monck, Duke of Albemarle. London, Murray, 1915.)

${ }^{8}$ Minutes of Council of Famaica, MS Archives of Jamaica, v 3b, 6 Oct, 1688.

9 fournals of the House of Assembly, Aikman, Jamaica, 1811, 1, 152, 7 March 1695.

10 Gournals of the House of Assembly, Aikman, Jamaica, 1811, 1, 164, 10 June 1696.

11 Fournals of the House of Assembly, Aikman, Jamaica, 1811, 1, 236, 17 April 1702.

12 Patents, Archives of famaica, 1674, 6, 74

13 Deeds, Island Record Office, 1679, 11, 29.

14 Deeds, Island Record Office, 1693, 24, 151.

15 Deeds, Island Record Office, 1710, 46, 107.

${ }_{16}$ Index to Wills, Island Record Office, Wills, 1735, 20, 24 (missing).

17 Deeds, Island Record Office, 1741, 111, 72 and 174.

18 Deeds, Island Record Office, 1741, 112, 43. 